\title{
India's carbon dioxide trap
}

\section{BANGALORE}

Encompassing most of central and western India, the Deccan Traps is the world's largest continental flood-basalt province outside Siberia. In the 1970s, it was a candidate for storing nuclear waste, but fears of groundwater contamination killed that idea. Now it is being proposed as a site for locking away another global nuisance, carbon dioxide $\left(\mathrm{CO}_{2}\right)$ - perhaps enough to make a significant dent in global warming.

The Deccan Traps is a thick pile of solidified lava from volcanic eruptions 65 million years ago. Indian and American geologists have launched a joint study to see how well they can trap the $\mathrm{CO}_{2}$ that has been captured from coal-fired power stations within and below the basalt layers.

Inspiration for the project came from research at the Pacific Northwest National Laboratory (PNNL) in Richland, Washington, which found that water saturated with $\mathrm{CO}_{2}$ reacts rapidly with basalt to form stable carbonate minerals (see Nature 444, 792-793; 2006). Many countries have considered capturing $\mathrm{CO}_{2}$ from power stations and storing it in aquifers or used oil wells, but there is always a risk that the dissolved gas could escape. If the gas could be converted into solid minerals within rock, however, it could be locked away long-term.

Pete McGrail of the PNNL reported the findings to a conference on $\mathrm{CO}_{2}$ capture and storage held in Hyderabad in India on 12-13 January. The US Pacific Northwest has similar basalt deposits, which McGrail's group now estimates could hold more than 50 gigatonnes of $\mathrm{CO}_{2}$.

"We are lucky to have the Deccan Traps, which is much bigger," says Ramakrishna Sonde, executive director of the National Thermal Power Corporation (NTPC) in New Delhi, which builds and runs India's coal-fired power stations. The NTPC is collaborating with the PNNL and the National Geophysical Research Institute (NGRI) in Hyderabad on the pilot study. Sonde says that he tentatively estimates that the Deccan Traps might be able to hold 150 gigatonnes of $\mathrm{CO}_{2}-$ as much as the world's power industry might emit in 15 years.

The three-way project, to which India

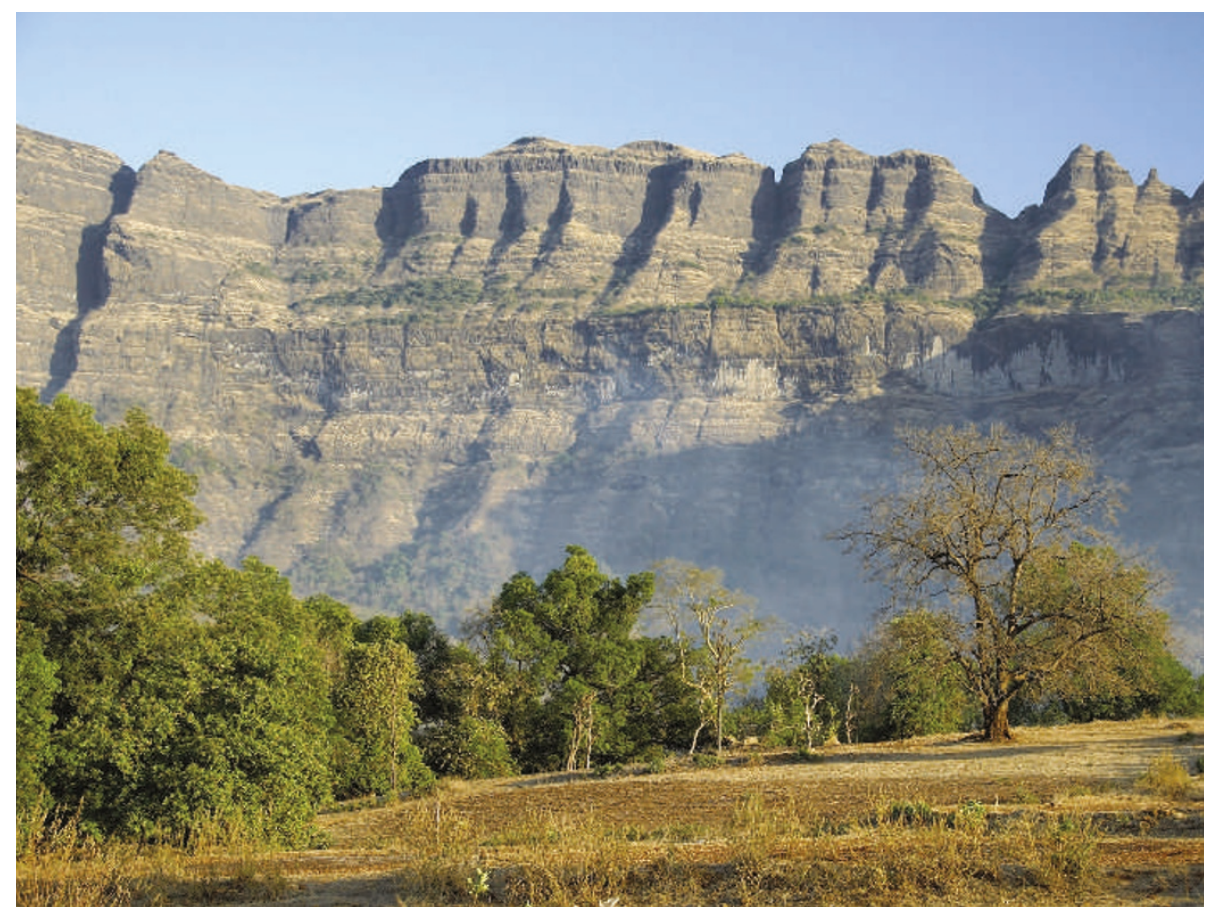

The basalt layers in India's Deccan Traps could be used to store huge amounts of carbon dioxide.

has committed US\$1.3 million, is one of the 17 initiatives endorsed by the Carbon Sequestration Leadership Forum, a voluntary climate initiative of which India was a founding member. "We look at coal as a dominant energy source, so $\mathrm{CO}_{2}$ sequestration is something we cannot ignore," Malti Goel, a senior official in the Indian science ministry and co-chair of the Hyderabad conference, told Nature.

NGRI scientists admit that basalt isn't very porous, making it hard to disperse $\mathrm{CO}_{2}$ through the rock, but say that this is compensated by its high reactivity with the gas. The ultimate idea is to pump supercritical $\mathrm{CO}_{2}$ into porous sedimentary rocks below the basalt layer. The gas would move upwards though the rock and react with the basalt above, forming a 'cap' that would stop any unreacted gas from escaping.

Some geologists, however, seem to be sceptical about the whole project. "I will not recommend $\mathrm{CO}_{2}$ sequestration in volcanic areas," says Kiran Shankar Misra, deputy director general of the Geological Survey of
India. "These are regions that are hot, and the basalts are highly fractured." He says that he is worried that the heat in the rock would cause the dissolved $\mathrm{CO}_{2}$ to become gaseous, and that it could then seep out through the fractures. "The $\mathrm{CO}_{2}$ will not stay there."

Hetu Sheth, a geologist at the Indian Institute of Technology, Bombay, points out that unlike the Columbia River basalts, which are only 14 million to 17 million years old, the Deccan lavas are highly weathered, meaning that they will already have reacted with $\mathrm{CO}_{2}$ in the air to a certain extent. "Their capacity for reacting with newly injected $\mathrm{CO}_{2}$ may therefore be low, certainly lower than the Columbia River basalts," says Sheth.

Before any $\mathrm{CO}_{2}$ is injected into the Deccan basalts, an initial phase of the project, scheduled to take 18 months, will characterize the permeability and porosity of the rock. It will also look at the nature of faults within the rock, to determine how $\mathrm{CO}_{2}$ would flow through the rock once injected. The PNNL is due to start pumping $\mathrm{CO}_{2}$ into the Columbia River basin basalts later this year, a project that Sonde says India is "keenly watching".

K. S. Jayaraman 